\title{
QUALITY OF GOURMAND PRODUCTS AND SERVICES AND MODERN TRENDS IN RESTAURANT INDUSTRY
}

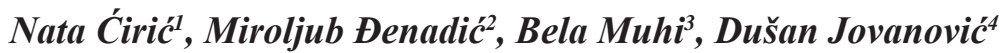

\begin{abstract}
Summary
Improving Hotel offers by introducing different contents and services (swimming pools, bars, conference rooms, specialized restaurants, diverse and attractive cuisine), with strategic and holistic approach to the hotel - tourist activities, can lead to increased tourist traffic and tourist spending. The modern touristic demand is very critical and sophisticated, particularly in the terms of content and new culinary trends. Religious customs, traditions and different ways of living, vegetarianism, organic food, healthy food, slow food etc., determine the specific consciousness of the choice of foods and nutrition for many tourists. The restaurants known for their fine gastronomy and service are in a stronger competitive position than restaurants that do not keep the continuity of high quality products and services. Creating a restaurant with an organic, macrobiotic or vegetarian food can be a significant form of marketing strategy aim to establish a superior quality catering industry products and achievement of competitive advantage in that respect.
\end{abstract}

Key words: catering, hospitality, strategy, quality

JEL: Q13, Q18

\section{Introduction}

The development and improvement of hotel and restaurant business leads to improvement and development of other directly or indirectly related activities. In this article the agricultural products which are of interest to the tourists, with their desire to their consumption, have been pointed out. This refers both to the national and international level. The twenty-first century is the century of new technologies and innovations in many areas of the economy and society, including IUU agriculture and food industry (crop lands, processing and food processing). It is

1 Ph.D., Ministry of Economy, Kneza Miloša 20, 11000 Belgrade, Phone: +381 62204 332, E-mail: nata.ciric@gmail.com

2 Ph.D., Recreatours Adria, Cara Dušana 48, 11000 Belgrade, Phone: +381 63262 077, E-mail: djenadic.miroljub@gmail.com

3 Ph.D., Educons University, Faculty of Business Economy, Vojvode Putnika 87, 21208 Sremska Kamenica, Serbia, Phone: +381 63533 720, E-mail: muhi.bela@gmail.com

4 M.Sc., Ph.D. student, University of Novi Sad, Faculty of Agriculture, Trg Dositeja Obradovića 8, 21000 Novi Sad, Serbia, Phone: +381 62303 122, E-mail: duda.jovanovic@gmail.com

EP 2014 (61) 2 (409-422) 
expected that the skill and knowledge regarding to the creation, promotion and development of food products and culinary skills and services will achieve outstanding quality. This will require proper management and quality of gourmet products and services, as well as human resource management and their knowledge in this field. Knowledge, information, creativity and skills are certainly the greatest capital in the hotel industry and in the catering and gastronomy industry. Strategic effort means that all the activities of hotel companies in the market should be evaluated solely from the standpoint of its ability to improve its position in the targeted markets. Satisfaction means that it is necessary to meet the needs of hotel guests, because for the hotel company which aspires to meet business objectives in the market economy, consumer satisfaction is prerequisite for profit. A growing number of restaurant and hotel guests have special needs and requirements in terms of gastronomy. Restaurants with organic, macrobiotic or vegetarian food can be an original form of a strategy that differs from the competition, with desired positioning in the minds of certain target market segments and achievement of significant competitive advantages in that respect. Also, these special activities generate a marketing relationship with clients and provide loyal customers.

\section{The quality of products and services as a strategic tool}

It is widely accepted that the quality means compliance with the requirements. It is assumed that once the specification is given, quality measures ensuring compliance with the specification. This is the definition of quality from the point of supply. Unlike previous definition, when the quality is measured from a user perspective, Kotler gives the following definition: "Quality is the total of features/characteristics of products or services that have the particularity to satisfy the expressed and implied needs." In his opinion the company to fulfill the needs of consumers mostly is called a quality company (Milisavljević, 1998). It is considered that there are four stations in the use of quality as a strategic asset in achieving competitive advantage in the market. In the first stage of evolution, the stress is on an agreed quality. It is necessary to provide quality products and services given in the standards of quality. In the second stage of evolution, the stress is on the customer's satisfaction. Thus the focus shifts from internal operations to external operations, and consumers. In the third phase the stress shifts to quality viewed in relation to competing companies. This requires reliance on analysis of the market trends and segments, as well as how consumers make decisions about the choice of the products between different products on the market. Quality as a strategy means permanent access to the fourth stage of evolution. This is a qualitative step forward to the quality of products and services (Milisavljević, 1998).

Building of international standards (ISO standards) and a recognized structure for quality management and assurance is achieved through a series of standards ISO 8402, ISO 9000ff, ISO 10000ff, 14000ff ISO, EN and other standards 45000ff whose number increases every day. All ISO standards are generic and can be adapted to any business, both in production and in service companies. Standard ISO $9000 \mathrm{ff}$ has not expressed explicitly in particularly how product or service must be created. They describe the character of strategic quality management as follows: the composition of quality is realized through a process, which is located within the business functions or even exceed the limits of these functions. 
The quality of the ISO standards define as unconditional guidance on the expectation of customers, associates, owners, suppliers and society at all levels. ISO 9000 series standards are international standards that are the minimum requirements, to meet the quality. Those guidelines stipulate that they should be applied, but not how to set REQUIREMENTS addressed (Cerović, 2003).

\section{The strategic approach to quality of the hotel products}

The hotel products can be considered as heterogeneous, interconnected and related services and as such, represents an ideal area for the introduction of technological and social innovation, which means improving the quality of the hotel products. Improvement of the hotel product, the implementation of innovation in business is hotel management response to the technological, economic, psychological and social changes in the environment. A critical point in this process is the identification of innovation by the hotel management that will contribute in the best way to improve the quality of hotel products/services.

The strategic concept of hotel management on the quality of tangible and intangible elements of the hotel products will be the way of gaining competitive advantage in the tourism market. In the modern business of hotel and tourism enterprises, there are many reasons to highlight the importance of applying quality management (Bakić, 2002):

- Sharpened competition in the market of hotel services

- Significantly increase the level of attention to consumerism

- The observed increase in sophistication of the market of hotel services and hotel products

- Greater use of modern technology as an impulse to the raising of hotel services to the next level.

- The Companies are guided by strategy of increasing of hotel products and services quality.

It can be concluded that the quality of hotel products and services has a significant influence on the position of the hotel company in the market and the level of market share, which significantly contributes to increased profitability in the long term financial performance and profitability. For that reason, the hotel company managements recommend a strategic approach to quality of the hotel products, which means respecting the following circumstances:

- Following marketing orientation, the hotel company has to constantly adjust the quality of the own products to the needs and demands of the changing tourism market.

- It is essential that market research has to identify the attributes of hotel products, which are crucial for the realization of that product on the market.

- It is necessary to attend a real quality that can be defined as a combination of quality score, as seen by consumers and employees.

- It is necessary to analyze the quality of hotel products and introduce the following parameters: the elasticity of demand on the quality of hotel product, as well as the elasticity of demand on the individual elements of quality and

EP 2014 (61) 2 (409-422) 
- Recommendation to the hotel management to adopt the philosophy of integrality of the hotel product.

The basic assumption for superior quality hotel products and services and competitive advantage in that respect, is the functional quality of the process, which is observed in the interaction between the hotel guest and the hotel service provider - is the moment of truth. This relationship, as stated in the literature, includes not only the interaction, but also acquire a sort of the guests impression to the hotel architecture, accommodation, or de-lightness to the variety of the gastronomic products and dishes (large pleasure factors wow-factors), (Ninemeier et al., 2005).

The interaction in the creation and delivery of hotel products and services is the dimension of the quality of service that is dominant and is manifested by the kindness, courtesy, flexibility and the tendency of employees to contact and the ability to act as a "part-time marketers of the company".

The process of improving the quality of hotel product (service) has excellent goal to increase sales revenue, and reduce costs by reducing or eliminating errors and omissions in the process of services. Making profitable decisions related to the costs of improving quality is a key management problem. Also, all efforts to improve the quality must be financially justified, including knowledge where efforts should be made and when is necessary to reduce their investment (Ljubojević, 1998).

\section{Total Quality Management (TQM) in Restaurant Industry and Gastronomy}

Gastronomy or gastrology comes from the Greek word which means "gaistri" stomach and "nomos" - the knowledge and the law. Gastronomy includes everything related to cooking, chef skills and in the broad sense includes gastronomery, epicurisme, in the broadest sense, the relationship between culture and food, nutrition and art, culinary art. Gastronomy is one of the interdisciplinary fields, since the preparation, decoration, display and setting of food, often is accompanied by music, dance, visual arts, but also has points of contact with biology, agronomy, etc.. Scientific discipline that studies the cooking and gastronomy, is known as molecular gastronomy. ${ }^{5}$

First application of high-standard and restaurants is connected to the second half of the 19th and the first half of the 20th century and the famous hoteliers and owners of hotel chains, Ritz, "Cesar Ritz-a-a. Cesar Ritz was a visionary at the time. He knew that restaurants and pubs are a significant part of the hotel product. In a number of hotels that he has built, a special place occupied a luxury restaurant with fantastic cuisine. His guests were the best known personalities of the time, where King Edward VII took a special place. In much the fame of his sentence related to the RITZ HOTEL, which read: "Where is the "RITZ", I am there." Belinger, wellknown restaurateur and owner of the time the famous Parisian restaurant "VOISON," said that the Cesar Ritz is a giant in the field of gastronomy. The name of Cesar Ritz in professional circles in Europe was the brand name for quality catering services (Chwarz, 1995).

5 available at: http://sh.wikipedia.org/wiki/Gastronomija, Wikipedia, the free encyclopedia. 
Today, many well-known hotels in the world are developing a tradition of good food to raise the overall quality of service, whether it's national cuisine or international specialties are prepared. Certainly, agricultural products, vegetables, fruits and beverages (e.g. wine, spirits and the like are treated as agri-food products), must meet certain quality standards, as well as current trends in tourism demand for healthy food.

In modern business of hotel and tourism enterprises, total quality management (Total Quality Management) is a relatively new philosophy, and specific actions aimed at improving service quality. It should be noted that the activity of continuous quality improvement and preventive rather than corrective process (Milisavljević, Todorović, 1995). The application of TQM in the hotel industry in the first plan emphasizes two dimensions (Bajić, 2002):

- Major changes in the organizational structure of the hotel companies, management instruments and changes in attitudes and behavior of all employees in the company;

- Support of all employees applying this concept and the introduction of an acceptable method to maintain it.

The characteristics of the organization oriented towards TQM concept:

- Planning horizon: long-term views on the vision, mission and strategy

- Motivation: customer satisfaction

- Investments: small-progressive,

- Development: aimed at innovation.

The characteristics of classic business-oriented organizations:

- Planning horizon: short-term views on the vision, mission and strategy of the company

- Motivation: profit

- Investments: large

- Development in accordance with tradition.

Of the crucial importance to the acceptance of the concept of TQM is top management's ability to impose a new system of values in organizational and cultural environment, to transform the way of thinking in the behaviour of employees, and to choose the successful implementation of the method. In hospitality, by focusing on satisfying the ever-changing customer needs by creating individualized approach, responsiveness, empathy and trust, hotels over time get regular customers who can in return always expect to get the same level of service quality. In that process, hotels create a recognizable product, which increases there market visibility and profit. Reaching company's objectives by focusing on customer needs is the essence of TQM in hospitality.

\section{Alternative ways of eating good food}

Each hotel guest, during their stay in a hotel or restaurant, will be treated not as a part of a tourist mass (mass of tourists), but as a separate individual with their (its) desires and habits. They want all their senses to be satisfied and the whole food consumption experience to be 
unforgettable. Tourists often like to try other, hitherto completely unknown tastes of various agricultural products. Agricultural production is now able to produce different varieties of agricultural products. Also, the manufacturing industry has achieved a high quality and large number of different ways of processing agricultural products for human consumption. For tourists it is particularly interesting to include healthy, organic food in the tourist industry. One could make a large number of distributions of the customers (tourists) or their segmentation according to the requirements and preferences regarding the consumption of food and beverages in the catering and hotel businesses and restaurants.

Here are just three segments of consumers (tourists):

- Those who want a vegetarian nutrition

- Those who want a macrobiotic nutrition and

- Those who want eco-gastronomic nutrition.

In the following, we will analyze all three terms, as in the past (during the middle of the 19th century), and today's modern, modern society.

Once, not too long ago, the food was simple and natural. For many, this means a trip back in time of the childhood when tomato was more sweet-scented, though not so shapely as it is today, when the apples were still full of vitamins, not pesticides, when all fish was good for the health and when more beef could be eaten without risk of dementia. Today, term healthy eating, primarily refers to vegetarian food, or food that excludes red meat. The first Vegetarian Society was founded during the middle of the 19th century in London, and now has hundreds of millions of members worldwide who make $3 \%$ of the total population. Many who were inspired by the new nutrition wrote down their thoughts and one of them that was found in an ancient Egyptian papyrus reads: We live on a quarter of what we have ingested, doctors live on the remaining three quarters. ${ }^{6}$

There are many subdivisions within the concept of vegetarianism, which unites them all. People who eat this way can be divided into semi-vegetarians, lacto-ovo-vegetarians, and vegan lacto vegetarians. However, there are semi vegetarians, who in their meal sometimes include fish or chicken, dairy products, eggs, but never red meat. Then, "lacto-ovovegetarians" who consume milk, dairy products and eggs, and vegans that eat only foods of plant origin. Looking from a nutritional standpoint, the more restrictive diet, the greater the possibility of a lack of certain nutrients. Semi vegetarian, well planned nutrition is often associated with a balanced, ideal diet, and the occasional consumption of fish and poultry, identified with the Mediterranean cuisine, is the model recommended by medical and nutritional fields. With adequate education and planning, such nutrition can be of very high quality and nutritionally valuable. When talking about alternative ways of eating, we must mention macrobiotics. It represents a comprehensive approach to healthy eating that includes food choices, food preparation methods, and the manner in which prepared food is eaten. Macrobiotic nutrition consists of whole grains, legumes, vegetables, nuts and

6 available at: http://www.gastro.hr/ekogastronomija-2219.aspx, Gastro.hr - web portal for food culture. 
seeds, fermented soy products, and a frequent use of algae as part of soups and stews. The principles of macrobiotics is based on the fact that each foodstuff has its own energy, which depends on the location and direction of growth in food, climate and season, and thus food affects your mood, thoughts and health. In other words, macrobiotics teaches that food is a mean to achieve the balance of physical, psychological and mental level, and therefore very carefully selected ingredients are combined. ${ }^{7}$

More than half the adult population of the European Union is overweight and $15.5 \%$ of adults are obese. In countries such as the United Kingdom, Eire and Malta, the percentage stands at around $20 \%$. The growth rates of these percentages are a serious cause for concern: obesity is, in fact, a risk factor for numerous health problems, such as hypertension, diabetes, cardiovascular pathologies, respiratory problems and some forms of cancer, and the risk of death increases considerably once the overweight threshold has been crossed. The effects of malnutrition, obesity and overeating are not only serious from the public health point of view, but may also have severe repercussions on a country's health budget. Suffice it to think that $7 \%$ of health spending in Europe is accountable to obesity-related pathologies. The factors that contribute to obesity are manifold, but among the main ones are overeating and unbalanced diets. The relationship between people and food production, processing and consumption has been progressively lost. The simplification

and standardization of food production, processing and consumption methods - for the sake of greater "speed" and globalization, seen as mere homologation — has progressively eroded food culture, which used to be a common heritage, and imposed "price" as the main criterion for making choices and, as a consequence, for organizing one's diet. On the one hand, this has signified the debasement of the role of food, which no longer represents an essential resource worthy of respect, since it can be consumed in excess (overeating) or, on the contrary, wasted without immediately visible consequences ( $42 \%$ of waste is recorded at domestic level). On the other hand, it has caused consumers to opt for cheaper foods, often of poor quality. As Slow Food has been explaining for years, producing good, clean and fair food has its costs. A low price is often made possible by the use in the production process of industrial methods that allow production costs to be cut. These production methods are obviously typical of the large scale which, by further lowering costs, hence selling prices, benefits substantially from CAP (Common Agricultural Policy ${ }^{8}$ ) economic support. If we consider that food produced by agroindustry is easily available through large-scale retail channels, it is easy to see how the agri-food system itself is at the forefront in encouraging improper diets and the consumption of low quality food (Slow Food, 2010).

Price of healthy food products, alternative ingredients and special requirements of hotel guests is the most important criterion. If the consumer is willing to pay for a particular agricultural product or a gastronomic specialty not only will they be satisfied as customers, this will also

7 available at: http://www.gastro.hr/ekogastronomija-2219.aspx, Gastro.hr - web portal for food culture.

8 available at: http://ec.europa.eu/agriculture/cap-history/index_en.htm, European Commission's Agriculture and Rural Development Policy.

EP 2014 (61) 2 (409-422) 
be the right signal that the farmer, manufacturer and gastronomes, have succeeded in their intention. Economics of Agriculture, which among other things includes the marketing of agricultural products in the tourism and hospitality, implies that the farmer has to know where his market is, which of his products consumers (tourists) want to buy, what they want to eat in the hotels, how much are they willing to pay for it, as well as the quality of agricultural, i.e., gastronomic products they seek and like.

Republic of Serbia adopted a Strategy of Agricultural Development in 2005, which would allow the smooth development of agriculture and the integration of agriculture in the European Union. The strategy provides the changes that need to be made in the agricultural sector. They include three major elements, namely: complete transition from a socialist to a full market economy, integration and EU accession, a radical reconstruction and modernization of the entire agricultural sector, and the establishment of market economy, which will have a strong impact on the role of government in agriculture and the relations between agricultural producers, consumers and government (Strategy for Agricultural development of Serbia). Today's agricultural strategy reflects nearly half a century long changes in food production priorities. The initial goal to increase food production, almost regardless of cost, is replaced by controlling the excess production and excessive costs. Also, it now redirects to meet a number of different social and environmental objectives through mechanisms that are substantially separated from production (Cvijanović et al., 2011).

Increase of the consumption of vegetables in relation to meat consumption in most developed countries of the World

In all previous periods of time the amount of meat consumption has been increasing in accordance with social status. In most developed countries of the world, the meat is progressively becoming the food of lower stratum of the society, and citizens who earn well and have university degrees eat significantly less meat or sausage. This is the result of a national study about nutrition published in Germany which is engaged in the relationship between consumption of certain foods, and social status. There is a danger that meat foods is becoming lower social stratum, said study co-author, Achim Spiller, professor of food marketing at the University of Goettingen.

In all previous periods, the quantity of consumed meat has been increased in accordance with social status. One of the causes of the degradation of the reputation of the meat industry, which has been struggling for years with scandals related to animal disease, is the use of prohibited means in breeding and treatment of livestock. In addition, a significant number of citizens are ready to reduce the consumption of meat for health reasons, and because of warnings of environmental experts that meet production adversely affects to the global climate change. Meat consumption in Germany reduced from more than $66 \mathrm{~kg}$ per capita/ year in the mid- 1980 s to $60.3 \mathrm{~kg}$ per capita/ year. ${ }^{9}$ In the US, meat consumption has

9 available at: http://www.rts.rs/page/stories/sr/story/14/Nauka/56133/Meso+postaje+hran a+ni\%C5\%BEih+dru\%C5\%A1tvenih+slojeva.html, Radio and Television of Serbia, online edition, news. 
decreased by $12 \%$ between 2007 and $2012 .{ }^{10}$

Regardless of the previous data, globally speaking, we can register the excessive production and consumption of meat and unhealthy fast food. Even $18 \%$ of greenhouse gas emissions come from livestock farming. How many animals are needed for this amount of gas? A frightening fact is that $30 \%$ of the Earth's land surface is directly or indirectly devoted to raising animals we eat. It is anticipated that this amounts will double in the next 40-odd years. ${ }^{11}$

"U.S.A. companies introduce new practices into their operations, which they believe will have positive effect on mood and health of employees. One of them was Pepsi Co., which has an organic vegetable garden where employees can pick up fresh vegetables. Besides being a creative way to motivate employees, this practice is partly compensated for the lack of a salary raise at this time of financial crisis. The gardening was also accepted by Google and Yahoo, and Toyota is growing large quantities of pumpkin and tomato in the factory. Of course, for successful vegetable ripening, somebody has to cultivate it, so employees agreed to volunteer so they can bring fresh vegetables home every day". ${ }^{12}$

\section{Eco-gastronomy in hotels and restaurants}

The motive for traveling or accommodating at the hotel can often be just the food that it offers. It is necessary that hotels and gourmet restaurants conceptualize their products to the targeted segment of consumers and thus can be differentiated from the competition. For example, restaurants such as Chez Panisse in Berkeley, Lidias in Kansas City and the Johnstones chain Chipotle Grill, use natural, organic food in order to distinguish themselves. These restaurants have developed a network of farmers who supply them with fresh products that are manufactured by the standards of the restaurant. Hotels and restaurants, which are creating memorable experiences are positioned well in the market (Steinberg, 2004). The food is a basic necessity of life that connects us with the rest of the world and is an integral part of our future.

When Carlo Petrini, founder of the Slow Food movement that emerged in response to fast food, visited the University of New Hampshire in the UK, it has opened a new chapter in understanding food. Shortly after his departure eco-gastronomy was born. We want to show to everyone who is interested that it is not enough to put a carrot in their mouth. An important fact is the question of who breed the carrot, how it came to us, who produced the seed for it, as he served on a platter at the restaurant, who it is and how to serve guests... and a number of other issues, said in a recent Washington Post interview Daniel Winans, one of the speakers at the study of eco-gastronomy in New Hampshire. The professor agrees that

10 available at: http://www.foodnavigator-usa.com/Markets/What-s-driving-the-decline-inUS-meat-consumption, Food Navigator - News on Food \& Beverage Development.

11 available at: http://www.bastabalkana.com/2011/08/savremena-ishrana-i-sta-nije-u-redusa-njom/, Balkana Garden - Natural, life and style web magazine.

12 available at: http://www.gastro.hr/ekogastronomija-2219.aspx, Gastro.hr - web portal for food culture.

EP 2014 (61) 2 (409-422) 
a program that combines nutrition, agronomy and catering approach will drastically affect the traditional love to pizza and beer, however, is optimistic, because people will learn to observe the food from many perspectives to better understand principle of sustainable food production and consumption.

Since the program launched eco-gastronomy, there are more and more interested into it, as the term of eco-gastronomy is slowly spreading around the UK. There still exist as much as 19 departments that deal with food and agriculture at the prestigious U.S. Yale University, which are very popular among students majoring psychology, biology and politics of food. In the United States, number of university departments associated with food increased more than $50 \%$ over the past five years, so it might be perceived as a sort of trend. What is strongly marking the study of food is interdisciplinary. New Hampshire students spend time not only in the classrooms during their studies, but in the kitchen, laboratory and farm as well, and they are expected to spend a semester at the University for the culinary arts in Pollenzo, Italy to prepare for the career of the professionals who care about what we eat and how we get that what we eat. We became aware of the growing interest of young people for food and sustainable development and their desire to understand the relationship between the local, regional and global food system, says Joanne Curran-Celentano, professor of nutritional sciences noting that eco-gastronomy studies are created with the aim to encourage students to seek deeper food understanding.

Eco-gastronomy offer in the restaurants and hotels should take more and more space. For that you need to make the differentiation in the reputable hotels and restaurants of gastronomic delights from a large number of tendered products. Differentiation of gastronomic offer, which excites the customer, offers something new, which can lead to excellent opportunities for public relations, customer loyalty and higher profits (Kotler et al., 2010).

\section{Management of restaurants with alternative ways of nutrition}

The restaurant which is known for its fine gastronomy offer and services is in a stronger competitive position than restaurants that do not keep the continuity of high quality products and services. Quality service creates a marketing relationship with restaurant guests and creates loyal customers.

Creating a restaurant with organic, vegetarian or macrobiotic food takes place in several phases: the design concept of the restaurant, the selection of recipes, food preparation and photography, design, printing menus... Such projects are extremely demanding and complex, but primarily it is necessary to bring together people who are extremely professional and creative in their field of action, so that all elements are molded into an attractive design. It is necessary to show the guests that in this, limited foodstuff culinary approach, it is possible to design and prepare meals that look attractive, as well as meals in every other culinary direction.

Vegetarian cuisine is considered as a cuisine which omits a number of ingredients and therefore many are skeptical towards it. It is therefore necessary to make the most of all 
natural foodstuffs as much as possible in order that food is acceptable. There is a need for a pleiad of farmers who work for organic food restaurant. Currently the ratio is such that in these restaurants, about $80 \%$ of served vegetables are truly organic (vegetables), and the rest is purchased from reputable small producers that are known to adhere to standards.

There is a great difference in tastes and habits of the individual continents. For example, Americans mix fruit with everything, mixing sweet, sour and spicy. Everything is acceptable there. However, Europeans for example are used to specific tastes and extreme exoticism does not pass. Consumers accept experiments to some extent, otherwise, this approach does not have success in the long run. Guest is looking for something familiar, possibly with added elements from other cuisines. A very similar situation is in Serbia. Our customers love to try something new, but they rather prefer relatively distinctive tastes. Innovation in gastronomy should encourage modern tourist not only to recognize food as "healthy", but to come to restaurants because of the very interesting taste, a combination of elements from various cuisines merged into new and delicious meals. In Serbia, a number of traditional dishes and drinks are characteristic to major entertainment and tourist events. A varied cuisine prepared in the manner and form that has not changed for centuries, creates an integral part of the interesting, attractive and alluring tourist offer of Serbia. Such gastronomic diversity, certainly a represents significant ethnographic wealth and it is an integral part of the cultural heritage of Serbia, but as well as an attractive and original tourist product that contributes to the positioning of Serbia as a competitive tourist destination (Đenadić, 2010).

Attractive kitchen interior is often found in restaurants and provides excellent opportunities for knowing and planning with culinary techniques, and it is important to say about the very foodstuff that are used, that they must come directly from the market and the market of proven suppliers. No artificial flavors, no ready-made sauces from the bag - just natural methods of discovering new flavors and combinations of socializing with food and wine. The high level of cuisine is not just one that is served in expensive and great restaurants. The title of "Haute cuisine" deserves every top bite, a product or rest place, no matter where we afford pleasure: the humble hut at the market or in a luxury restaurant that attracts a jet-set.

Management of the restaurant must comply with the profitability of the listed gastronomic products. If not, certain analyzes should be performed to find the possible ways of modification of the product and its return to profitability. If the analysis shows that the product should be deleted excluded, there are three choices: a gradual retreat, thinning, and finally the expulsion of products that do not make a profit (William et al., 1995).

\section{Conclusion}

Hotel and restaurant managers need to decide which aspects are most important for customer and to focus on them. One important element is certainly linked to the ratio of product quality and services and prices. For that reason, the quality level should be accompanied by adequate price of gastronomic products and services. Furthermore, the knowledge regarding

EP 2014 (61) 2 (409-422) 
hotel, restaurant and tourism business management must be continually upgraded, a lot of knowledge regarding the management of hotel and tourism businesses and restaurants must be continually updated. Business of the new era is characterized by the fact that competition is destructive. In this context, it is necessary to change the current management style to more competitive and to establish and build a system of cooperation, partnership, association (cluster association) and such like. This paper concludes that the tourist business in the future will be run only by those who recognize the optimal strategy development and improvement of quality of products and services. Business strategy must be formulated according to the type of business, choosing the targeted market and group of tourist products and services that will satisfy chosen market. The aim is to emphasize the need for innovation in the hospitality and restaurant industry, especially when it comes to innovations in cuisine. The luxurious, well-organized and the exemplary types of hotels and restaurants must make a package of products and services for pre-selected clientele that is willing and able to pay the price. This certainly applies to the catering facilities in the high category, i.e. serving healthy, organic and produced in a healthy way of processed food. This is so, because such products are still expensive, so only the big spenders can now afford them. Prices are currently high because there are still large segments of the consumer market for these types of food. However, due to the increasing desire of people to longer stay vital, young and very healthy, it is anticipated (predictions UNWTO) trend of rapid increase in the number of such clients, primarily in higher purchasing power, and later on in the lower strata of society.

\section{References}

1. Bajić, M. (2002): Menadžment totalnog kvaliteta u hotelijerstvu, Hotelska kuća, Ugoprogres, Beograd.

2. Bakić, O. (2002): Kvalitet usluge kao strateško opredeljenje hotelskog preduzeća, Hotelska kuća, Ugoprogres, Beograd.

3. Balkana Garden - Natural, life and style web magazine, www.bastabalkana.com/2011/08/ savremena-ishrana-i-sta-nije-u-redu-sa-njom/

4. Cerović, Z., (2003): Hotelski menadžment, Udžbenik sveučilišta u Rijeci, Rijeka.

5. Chwarz, W. (1995): Der Hotel Emfang, Hugo Mathaes, Verlag, Stuttgad.

6. Cvijanović, D., Simonović, Z., Mihailović, B. (2011): Težišta i ciljevi novijih reformi agrarne i regionalne politike Evropske unije, Ekonomika poljoprivrede, vol. 58, no. 3, pp. 359-370, IEP Beograd.

7. Đenadić, M. (2010): Zdrava hrana kao faktor turističke konkurentnosti Srbije, Ekonomika poljoprivrede, vol. 57, no. 4, IEP Beograd.

8. European Commission's Agriculture and Rural Development Policy http://ec.europa.eu/ agriculture/cap-history/index_en.htm

9. Food Navigator - News on Food \& Beverage Development, www.foodnavigator-usa. com/Markets/What-s-driving-the-decline-in-US-meat-consumption

10. Gastro.hr - web portal for food culture, www.gastro.hr/ekogastronomija-2219.aspx 
11. Kotler, P., Bowen, J.T., Makens, J.C. (2010): Marketing u ugostiteljstuu, hotelijerstvu i turizmu, Mate, Zagreb.

12. Ljubojević, Č. (1998): Marketing i menadžment usluga, Stylos, Novi Sad.

13. Milisavljević, M. (1998): Marketing; Poslovna škola Megatrend, Beograd.

14. Milisavljević, M., Todorović, J. (1995): Marketing strategija, Ekonomski fakultet, Beograd.

15. Ninemeier, J. D., Perdue, J. (2005): Discovering Hospitality and Tourism, Pearson, Prentise Hall, New Jesey.

16. Radio and Television of Serbia, on-line edition, news: www.rts.rs/page/stories/sr/story/14/ Nauka/56133/Meso+postaje+hrana+ni $\%$ C5\%BEih + dru $\%$ C5\%A1tvenih + slojeva.html

17. Slow Food (2010): Towards a New Common Agricultural Policy: Slow Food Policy Paper on CAP, Edt. Olmo, A., available at: www.slowfood.com/filemanager/campaign docs/SF_CAP_ENG_FULL. pdf

18. Steinberg, B. (2004): KFC cooks up yet another gambit, Wall Street Journal, New York.

19. Vlada Republike Srbije (2005): Strategija razvoja poljoprivrede Srbije, Beograd.

20. Wikipedia, the free encyclopedia: http://sh.wikipedia.org/wiki/Gastronomija

21. William, P., Ferrell, O.C. (1995): Marketing, Houghton-Mifflin Publishing, Boston. 


\title{
KVALITET GURMANSKIH PROIZVODA I USLUGA I SAVREMENI TRENDOVI U RESTORATERSTVU
}

\author{
Nata Ćirić ${ }^{13}$, Miroljub Đenadić ${ }^{14}$, Bela Muhi ${ }^{15}$, Dušan Jovanovic ${ }^{16}$
}

\begin{abstract}
Rezime
Unapređenje hotelske ponude uvođenjem različitih sadržaja i usluga (bazeni, barovi, kongresne sale, specijalizovani restorani, raznovrsna i atraktivna gastronomska ponuda), uz strategijski $i$ holistički pristup razvoju hotelsko - turističke delatnosti, vodi povećanju turističkog prometa i turističke potrošnje. Savremena turistička tražnja je veoma zahtevna i sofisticirana, posebno po pitanju novih gastronomskih sadržaja i trendova. Verski običaji, različiti načini i tradicije življenja, vegetarijanstvo, organska hrana, makrobiotika $i$ sl., determiniraju određenu svest o izboru namirnica $i$ ishrane kod mnogih turista. Restorani koji su poznati po dobrom kvalitetu svoje gastronomske ponude i usluge su u jačoj konkurentskoj poziciji od restorana koji ne drže kontinuitet u visokom kvalitetu proizvoda i usluga. Kreiranje restorana sa organskom, makrobiotickom ili vegetarijanskom hranom može biti značajan oblik marketing strategije u funkciji uspostavljanja superiornog kvaliteta ugostiteljskog proizvoda i ostvarivanja konkurentske prednosti po tom osnovu.
\end{abstract}

Ključne reči: gastronomija, hotelijerstvo, restoraterstvo, strategija, kvalitet

13 Ministarstvo privrede, Kneza Miloša 20, 11000 Beograd, Telefon: +381 62204 332, E-mail: nata.ciric@gmail.com

14 Recreatours Adria, Cara Dušana 48, 11000 Beograd, Telefon: +381 63262 077, E-mail: djenadic.miroljub@gmail.com

15 Univerzitet Educons, Fakultet Poslovne ekonomije, Vojvode Putnika 87, Sremska Kamenica, Telefon: +381 63533 720, E-mail: muhi.bela@gmail.com

16 Student doktorskih studija, Univerzitet u Novom Sadu, Poljoprivredni fakultet, Trg Dositeja Obradovića 8, 21000 Novi Sad, Srbjia, Telefon: +381 62303 122, E-mail: duda.jovanovic@gmail.com 